\title{
Afetlerde Kentsel Arama ve Kurtarmada Kullanılan Yöntemler ve Güncel Yaklaşımların Değerlendirilmesi
}

\author{
Gürkan Yılmaz ${ }^{1, \mathbb{D}}$, Sevda Demiröz Yıldırım² \\ ${ }^{1}$ Aydın Adnan Menderes Üniversitesi, Germencik Yamantürk Meslek Yüksekokulu, Acil Durum ve Afet Yönetimi Programı, Aydın. \\ ${ }^{2}$ Amasya Üniversitesi, Sabuncuoğlu Şerefeddin Sağlık Hizmetleri Meslek Yüksekokulu, İlk ve Acil Yardım Programı, Amasya.
}

\section{Özet}

Afet; deprem, tsunami, sel, heyelan, volkan patlaması, kasırga, hortum, uçak kazaları, tren kazaları, nükleer santral kazaları, patlamalar ve terör saldırıları gibi çok sayıda insanın yaralanması ve ölümü ile birlikte ciddi fiziksel tahriplerle sonuçlanan olaylar olarak tanımlanmaktadır. Deprem, terör saldırısı ve heyelan gibi olaylar sonucunda yapılarda meydana gelen çökmeler sonrası yıkılmış yapı altında mahsur kalan insan ve hayvanların bulunması için kentsel arama ve kurtarma çalışmaları önem arz etmektedir. Afetin ilk saatlerinde kentsel arama ve kurtarma çalışmalarının başlaması mahsur kalanların canlı olarak çıkarılma oranını arttırmaktadır. Illk 24 saat sonrası afetzedelerin hayatta olma oranı \%50 azalmaktadır. Özellikle depremlerle ilgili çok sayıda vaka çalı̧̧masından elde edilen verilere göre, afet sonrası hayatta kalanların \%50-95'i depremden sonraki ilk 24-48 saat içinde yerel halk tarafindan kurtarıldiğı belirtilmiştir. Fakat molozlar altında sıkışmış ve erişilmesi zor olan afetzedelere ulaşmada profesyonel ekiplere ihtiyaç duyulmaktadır. Çökmüş̧ yapı içerisindeki artçı sarsıntılar ve diğer nedenlerden kaynaklı (molozların kaldırılması veya sabitlenmesi sırasında oluşan çökmeler ve afetzede yakınlarının enkaz üstünde yakınlarını aramasından kaynaklı çökmeler vb.) oluşan ikincil çökmeler, tehlikeli kimyasal madde sızıntıları, gaz kaçakları ve kazazedeye erişimdeki geçiş rotalarının dar olması gibi olumsuz etkenler kentsel arama ve kurtarma ekiplerinin güvenliğini tehdit eden unsurlardır. Bu tehditler arama ve kurtarma personelinin kentsel arama kurtarma çalışmalarında tek bașına etkin ve verimli olmasını engellemektedir. Kentsel arama ve kurtarma çalı̧̧malarında yerel halk ve profesyonel ekipler ile birlikte köpekler, robotlar, sismik ve akustik (dinleme) cihazlar ve görüntüleme cihazları gibi aktörler de rol almaktadır. Bu aktörlerin her biri farkl görevler ile kentsel arama ve kurtarma çalışmalarında etkili ve verimli olarak kullanılmakla beraber çalışmaların bütünsel olarak yürütülmesini sağlama ve birbirini tamamlama özelliklerine sahiptir. Bu çalışmada kentsel arama ve kurtarma çalışmalarında görev alan afet gönüllüleri, profesyonel arama ve kurtarma personelleri, arama ve kurtarma köpekleri, dinleme ve görüntülü arama cihazları ile robotların arama ve kurtarma çalışmalarındaki pozisyonları incelenmiştir.

\section{Anahtar Sözcükler}

Afet, Arama, Kurtarma, Robot, USAR, INSARAG

\section{Methods Used in Urban Search and Rescue in Disasters and Evaluation of Current Approaches}

\begin{abstract}
Disaster is an event that results in serious physical and death of large number of people, because of earthquake, tsunami, flood, landslide, volcano eruption, hurricane, hose, airplane accidents, train accidents, nuclear power plant accidents, explosions and terrorist attacks. Urban search and rescue works are important for finding people and animals trapped under the collapsed structure after the collapse of buildings as a result of earthquakes, terrorist attacks and landslides. The initiation of urban search and rescue activities in the first hours of the disaster increases the rate of live removal of the stranded. The survival rate of the victims $50 \%$ decreases, after the first 24 hours. According to the data obtained from numerous cases especially related to earthquakes, it was stated that 50-95\% survivors after the disaster were rescued by the local people within the first 24-48 hours. However, there is need for professional teams to reach the victims who are trapped under rubble and are difficult to access. Secondary collapses due to aftershocks and other causes in the collapsed structure (collapses during removal or fixation of debris, and collapses due to the search of relatives on the debris of the relatives, etc.), dangerous leakage of gas, and leakage of access routes to the casualty. These are threats to the safety of urban search and rescue teams. These threats prevent search and rescue personnel from being effective and efficient in urban search and rescue activities. In urban search and rescue activities, local people and professional teams, as well as actors such as dogs, robots, seismic and acoustic (listening) devices and imaging devices are also involved. Each of these actors can be used effectively and efficiently in different tasks and urban search and rescue activities, but it has the characteristics of completing each other. In this study, the positions of disaster volunteers, professional search and rescue personnel, search and rescue dogs, listening and video search devices and robots in search and rescue activities were investigated.
\end{abstract}

$\underline{\text { Keywords }}$

Disaster, Search, Rescue, Robot, USAR, INSARAG

* Sorumlu Yazar: Tel: +90(256) 5632720 Faks: +90 (256) 5632724

E-posta: gurkan.yilmaz@adu.edu.tr (Yılmaz G), sevda.demiroz@amasya.edu.tr (Demiröz Yıldırım S)
Gönderim Tarihi / Received : 28/02/2019

Kabul Tarihi / Accepted : 03/07/2019 


\section{Giriş}

Afetler; toplumun tamamını veya bir kesimini etkileyen, günlük işleyişi bozarak insan faaliyetlerinin yapılmasını kesintiye uğratan veya imkânsız hale getiren, can ve mal kayıplarına neden olan flora (bitki varlığı) ve faunaya (hayvan varlığı) zarar veren doğal, insan veya teknolojik kaynaklı olaylardır (Karaman 2017). Afetler günümüzde çok sayıda insanın ölmesine, yaralanmasına ve ciddi mali kayıplara neden olmaktadır. Bu kayıpları en aza indirmek amacıyla afet yönetiminin tüm aşamalarına önem vermek gerekmektedir.

Bütünleşik afet yönetimi döngüsünde beş aşama bulunmaktadır. Bu aşamalar; zarar azaltma, önleme, hazırlık, müdahale ve iyileştirmedir (FEMA 2011). Zarar azaltma aşamasında, afet risk ve tehlikelerinin tespit edilmesi, büyük kayıplar yaşanmaması için gerekli önlemlerin alınması, toplumun afetlerle mücadele konusunda bilgilendirilmesi, bilinçlendirilmesi ve baş edebilme kapasitesinin geliştirilmesi, afet öncesi, sırası ve sonrasında uygulanan mevzuat ve idari yapılanmanın geliştirilmesi gibi faaliyetleri kapsamaktadır (İSMEP 2014). Zarar azaltma çalışmaları, afet ve acil durumların etkisini azaltmaya yönelik çalışmaları kapsamaktadır. Olası bir afette can ve mal kaybının en az seviyede olabilmesi için zarar azaltma çalışmalarının etkin ve verimli olarak yürütülmesi gereklidir (URL-1 2019). Önleme aşaması, risk oluşturabilecek tehlikelerin önceden belirlenerek tehlikenin oluşmasını engellemek ya da oluşturacağı zararı en aza indirmek için fiziki, sosyal ve siyasi önlemleri içerir (Ekşi 2015). Önleyici tedbirler, afet ve acil durumlara karş1 daha kalıcı koruma sağlamak amacıyla yapılır. Ancak tüm afetlerin önlenebilmesi mümkün değildir (URL-1 2019). Hazırlık aşamasında, afet zararlarını en aza indirmek amacıyla yapılan planlama, eğitim verme, afetlerde rol alacak aktörleri organize etme, kaynak envanteri oluşturma, örgütler arası etkileşimi sağlama, kaynakların tahsisi ve yerleştirilmesi gibi çalışmaları kapsamaktadır (Karaman 2017). Müdahale aşaması; afetin meydana gelmesiyle birlikte, arama ve kurtarma çalışmaları, ilk yardım ve tıbbi müdahale, gıda temini, güvenlik, geçici barınma, afetzedelere verilen psikolojik ve sosyal destek hizmetleri, mal ve çevre koruma gibi faaliyetleri kapsamaktadır. İyileştirme aşaması ise; afetler nedeniyle bozulan yaşamın normale döndürme ve yeniden yapılanmayı kapsamaktadır (Işık vd. 2012). Başarılı bir afet yönetimi sergileyebilmek için afet risk yönetimi (önleme, zarar azaltma ve hazırlık) ve kriz yönetimi (müdahale, iyileştirme) aşamalarının tümüne önem vermek gerekmektedir.

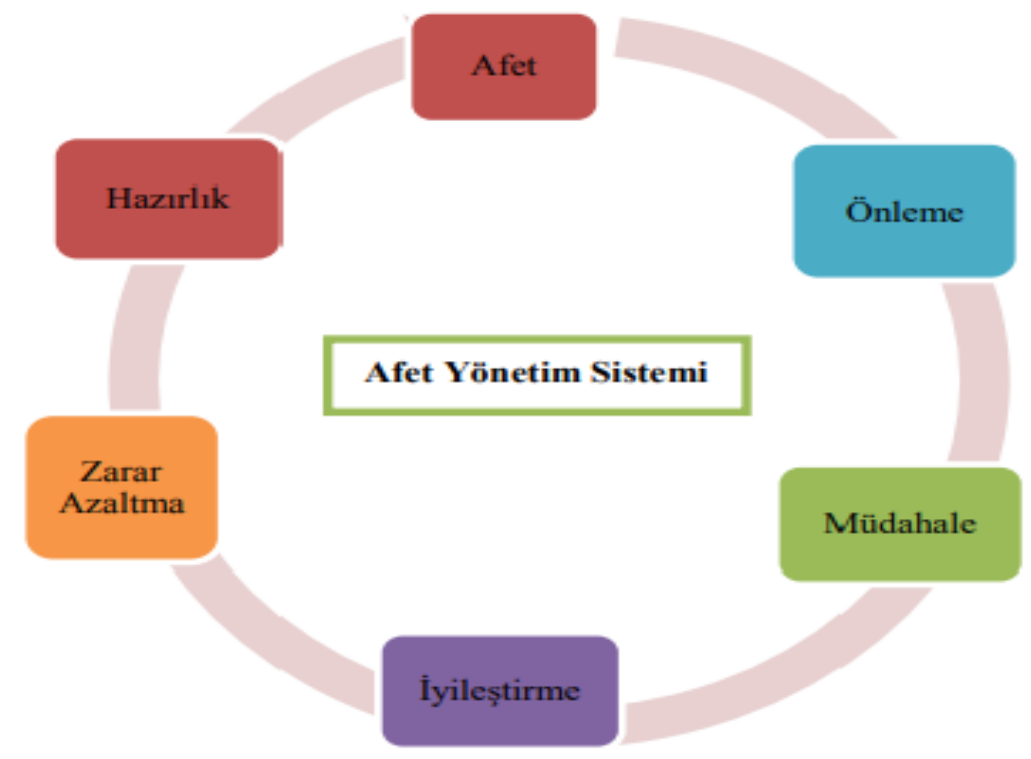

Şekil 1: Afet Yönetimi Sistemi (Usta vd. 2017)

Afet meydana geldiğinde kriz yönetiminin özellikle müdahale aşaması önem kazanmaktadır. Meydana gelen afetlerde afetin büyüklügü̈yle birlikte olumsuz çevresel koşullar, yetersiz malzeme ve donanım, teknik personel eksikliği, politik dengesizlikler ve altyapı eksiklikleri gibi olumsuzluklar can ve mal kaybının artmasına neden olabilmektedir. Bu nedenle afet sonrası can ve mal kaybının en aza indirilmesi için arama ve kurtarma faaliyetleri büyük önem taşımaktadır.

Afet ve acil durumlarda arama ve kurtarma çalışmaları afetin meydana geldiği bölgeye göre dağda, suda, kentsel gibi alanlara göre farklı olarak yapılmaktadır. Günümüzde şehirleşmenin artmasıyla birlikte, çok katlı yapıların sayısının artması, nüfusun büyük kısmının şehirlerde yaşaması, artan sanayi nedeniyle tehlikeli madde üretim ve depo alanlarının artması gibi nedenlerle kentsel arama ve kurtarma çalışmaları daha zor ve karmaşık hale gelmiştir. Artan depremler, tsunamiler, terör saldırıları, heyelanlar vb. afetler sonucu yıkılan yapılar sonrası enkaz altında kalanların canlı olarak çıkarılması kentsel arama ve kurtarma çalışmalarının etkili ve verimli olmasıyla ilişkili olduğundan kentsel arama ve kurtarma giderek artan bir önem kazanmaktadır. 


\section{Kentsel Arama ve Kurtarma}

Her yıl milyonlarca insan, farklı bölgelerde yaşanan depremler, tsunamiler, seller, heyelanlar, volkan püskürmeleri, kasırgalar, taşkınlar, terör saldırıları, nükleer santral kazaları ve endüstriyel kazalar gibi doğal, teknolojik ve insan kaynaklı afetlerden etkilenmektedir. Dünyanın genelinde idare ve yetkili makamlar yalnızca bu tür olaylara hazırlık için değil, sonrasında yeniden yapılanma konusunda da büyük miktarda kaynak harcamaktadır. Örneğin; Kocaeli Depremi (1999) sonrasında 4 milyar dolar ile yenilenebilecek konutlar için afet sonrası 16 milyar dolar harcandığ ortaya konmuştur. Van Depremi'nde (2011) ise 1,2 milyar dolar ile yenilenebilecek olan konutlar için afet sonrası 2 milyar dolar harcanmıştır (Akay 2017). Yaşanan afetler hem kamu hem de özel işletmelere ait tesislerin altyapısına ciddi şekilde zarar verebilir ve insanların refahını önemli ölçüde tehlikeye atabilir.

Bugün toplumların karşı karşıya kaldığı en acil ve hayati zorluklardan bir taneside kentsel alanların büyük ölçekli afetlere karşı savunmasızlığıdır. Deprem, kasırga ve terörist saldırısı gibi doğal, teknolojik ve insan kaynaklı afetler fiziksel altyapıya zarar vermektedir. $\mathrm{Bu}$ gibi durumlarda, USAR operasyonları afetzedelerin yerlerinin belirlenmesi, ilk tıbbi desteğin ve afetzedenin vücut stabilizasyonun sağlanması ve kurtarılması için gerçekleştirilir (Chen vd. 2012).

Afetlerin Epidemiyolojisi Araştırma Merkezi (CRED)'nin 2018 yılında yayınladığı rapora göre 1998-2017 yılları arasında meydana gelen afetler milyarlarca insanı olumsuz etkilemiş (yaralanma, evsiz kalma, yerinden olma vb.) ve bir milyondan fazla insanın ölümüne neden olmuştur. Raporda insanları en çok etkileyen afetler sırasıyla; sel, kuraklık, firtına, deprem, aşırı sıcaklıklar ve diğer afetler olarak sıralanmıştır. Ayrıca raporda 1998-2017 yılları arasında en çok ölüme neden olan afetlere baktığımızda ise sırasıyla; deprem, firtına, aşırı sıcaklıklar, sel, kuraklık, toprak kayması ve diğer afetler olarak sıralanmaktadır (CRED 2018). Deprem, firtına, terör saldırıları ve kitlesel kazalar gibi çok miktarda insan ölümüne neden olabilecek olaylar kentsel alanları etkilediğinde, kentsel alan yerleşim yerlerindeki kalabalık sivil nüfus ve sivil nüfusa ait altyapı yoğunlukları olayın etkisini arttıracağından dolayı müdahale süreci mümkün olduğunca hızlı ve etkili olmalıdır (Ochoa vd. 2007). Özellikle depremlerde ölüm ve yaralanma oranlarının yüksek olmasının ana nedeni yapıların çökme sonucu insanların enkaz altında kalmasından kaynaklanmaktadır. Büyük depremler gibi afetlere müdahale etmenin temel amacı; mümkün olduğu kadar fazla hayat kurtarmaktır. Böyle acil bir müdahalenin en önemli hedefi yıkılmış yapıların altındaki mahsur kalmış kişilerin kurtarılmasıdır (Peleg vd. 2018).

Hayatta kalan insanlar, hasarlı veya yıkılan binalarda oluşan doğal boşluk alanlarında (yaşam üçgenleri) bulunurlar. Afetzedeler için hayatta kalma olasılığı zamanla hızla azalacaktır (Bloch vd. 2016). Kentsel arama ve kurtarma çalışmalarında altın saatler olarak da bilinen ilk 72 saat en kritik saatlerdir (Ochoa ve Santo 2015). Yıkılmış yapıların altında kalan afetzedelerin canlı olarak çıkarılma oranı bu altın saatler dilimindeki ilk 24 saat sonrası \%50 azalmaktadır (Ochoa vd. 2007). Bu nedenle yıkılmış yapıların olduğu bölgelerde arama ve kurtarma faaliyetleri mümkün olduğunca hızlı ve etkili bir şekilde gerçekleştirilmelidir, çünkü hayatta kalanların sayısı arama ve kurtarma çalışmalarının etkin ve verimli yürütülmesi ile doğrudan ilişkilidir (Ochoa ve Santo 2015). Eğer bu kısıtlı zaman diliminde Arama ve Kurtarma (SAR) işlemleri hızlı ve verimli ise enkaz altında kalanlar kurtarılabilir (Bloch vd. 2016). Bu hedef için de müdahalenin en önemli adımlarından birini USAR oluşturmaktadır (Peleg vd. 2018).

\subsection{Türkiye'de Arama ve Kurtarma Çalışmaları}

Ülkemizde arama ve kurtarma çalışmalarıyla ilgili ilk düzenlemeler 13.06.1958 tarihli Resmi Gazete'de yayımlanan 7126 sayılı Sivil Savunma Kanunu'n çıkartılması ve bu kanun kapsamında İçişleri Bakanlığına bağlı oluşturulan Sivil Savunma Genel Müdürlüğü’nün kurulmasıyla başlamıştır (URL-2 1958). 1959-1986 yılları arasında afetlerde arama ve kurtarma çalışmaları, merkezde Sivil Savunma Genel Müdürlüğü personeli ile illerde yükümlülük esasına göre halktan oluşturulan ekiplerin valilerce afet bölgesine gönderilmesi ile yürütülmüştür. Bu sistemle Varto (1976), Gediz (1970), Burdur-Bingöl (1971), Van Muradiye (1976), Lice (1977) ve Erzurum (1983) depremlerine müdahale edilmiştir. Ancak arama ve kurtarma hizmetlerinin yürütülmesinde kullanılan araç-gereçlerin teknolojik gelişmelere uygun olması ve bu araçgereçlerin profesyonel olarak yetiştirilmiş ekiplerce kullanılması gerekliliğinin kabul görmesiyle birlikte 1986 yılında ilk defa Sivil Savunma Genel Müdürlüğü bünyesinde Türk Silahlı Kuvvetleri’nden (TSK) temin edilen ihtiyaç fazlası erlerden “340 Kişilik Sivil Savunma Arama ve Kurtarma Birliği” oluşturulmuştur. 1992 yılında TSK'nın asker ihtiyacı nedeniyle birliğe asker verilmemiş ve birliğin kadrolu personelden oluşturulması çalışmaları başlamış olup; 1993 yılında Ankara'da (61 kişilik), 1996 yılında İstanbul'da (24 kişilik) ve yine aynı yıl içerisinde (1996) Erzurum'da (30 kişilik) Sivil Savunma Birlikleri oluşturulmuştur. Oluşturulan bu üç birlik; ulusal düzeyde, Adana/Ceyhan Depremi (1998), Marmara ve Düzce Depremi (1999) ve çeşitli bölgelerde meydana gelen sel, heyelan ve çı̆̆ gibi afetler ile yurt dişında ise Yunanistan/Atina ile Taiwan'da (1999) ve El Salvador ve Hindistan'da (2001) arama ve kurtarma çalışmalarında bulunmuşlardır (Türker 2017; URL-3 2019; URL-4 2019).

Ağustos Marmara ve 12 Kasım 1999 Düzce depremlerinden sonra; 27.12.1999 tarihinde yürürlüğe konulan 586 sayılı Kanun Hükmünde Kararname'nin 2. maddesi ile Adana, Afyon, Ankara, Bursa, Diyarbakır, Erzurum, İstanbul, İzmir, Sakarya, Samsun ve Van olmak üzere 11 ilde çağdaş araç ve gereçlerle donatılmış "Sivil Savunma Arama ve Kurtarma Birlik Müdürlükleri” kurulmuştur. 
Birlik kurulmayan diğer illerde ise il sivil savunma müdürlükleri ve bünyelerinde oluşturulacak sivil savunma arama ve kurtarma ekipleri, ilçe sivil savunma müdürlükleri ile sivil savunma mahalli kuvvetleri kurulmuştur (URL-5 1999). Yakın tarihe geldiğimizde ise 2009 yılında 5902 sayılı Afet ve Acil Durum Yönetimi Başkanlığının Teşkilat ve Görevleri Hakkında Kanun ile arama ve kurtarma birlikleri yeni bir çatı altında toplanmıştır. 2009 yılında Sivil Savunma Genel Müdürlüğü kaldırılarak 5902 Saylı Kanun ile illerde İl Afet ve Acil Durum Müdürlükleri oluşturulmuş, 11 ildeki mevcut Sivil Savunma Arama ve Kurtarma Birlik Müdürlükleri İl Afet ve Acil Durum Müdürlüklerinin bünyesine dahil edilmiştir (URL-6 2009).

\subsection{Diğer Resmi Kurum ve Sivil Toplum Kuruluşları (STK) Ekipleri}

Tüm kurumların, afet durumlarında afet yönetişimi içerinde işbirliği halinde çalışması afet yönetiminin başarısını olumlu etkilemektedir. Ülkemizde afet yönetiminden sorumlu kuruluş olarak görülen Afet ve Acil Durum Yönetimi Başkanlığ1 (AFAD) ile birlikte devletin diğer kamu kurumlarının da afet yönetimine katkısı önem taşımaktadır. Ayrıca afet ve acil durumlarda gönüllüleri de kapsayan sivil toplum kuruluşlarının da önemi oldukça büyüktür. Bu nedenle afetlerin her aşamasında gönüllülere ve sivil toplum kuruluşlarına ihtiyaç duyulmaktadır. Afetler ve acil durumların sıklığı nedeniyle Türkiye'de kamu kurumları ve özellikle son zamanlarda sivil toplum kuruluşlarının oluşturduğu arama kurtarma ekiplerinin sayı ve niteliği gittikçe artmaktadır.

Türkiye'de kamu kurumuna bağlı olarak arama ve kurtarma çalışmalarına önemli katkı sağlayan Jandarma Arama ve Kurtarma Timleri bulunmaktadır. Jandarma Arama ve Kurtarma Timleri; kayak pistlerinde emniyet ve âsâyiş amaçlı devriye, arama ve kurtarma faaliyetleri, hasta ve yaralıları tahliye etme, dağlık ve ormanlık bölgelerde önleyici kolluk görevlerini icra etmek maksadıyla 1998 yılında teşkil edilmiştir. Ayrıca Jandarma Arama ve Kurtarma Timleri deprem ve maden göçüklerinden kaynaklı enkaz altında kalmış kişilerin kurtarılması ve tahliyesinde de görev almaktadırlar. (Türker 2017; İlhan 2013).

Cumhuriyet tarihinin en yıkıcı afetlerinden olan 17 Ağustos 1999 Marmara Depremi’nden alınan dersler sonucunda Türk Silahlı Kuvvetleri afetlerde faaliyetlerini daha profesyonel icra etmek amaciyla 28 Mart 2001 tarihinde Genel Kurmay Başkanlığı Güvenlik Kuvvetleri Komutanlığı'nca deprem, yangın, sel, çı̆̆ toprak kaymaları, kaybolmalar, KBRN ve büyük kazalar gibi doğal olan veya olmayan her türlü afette yurt içinde ve yurt dişında arama ve kurtarma faaliyetleri icra etmek üzere TSK Doğal Afetler Arama Kurtarma (DAK) Tabur Komutanlığı kurulmuş ve birlik uluslararası standartlarda teçhiz edilmiştir (Türker 2017; İlhan 2013; URL-7 2018). Maden kazalarında kurtarma, ocak yangını, göçük açma, enkaza girme, gazla mücadele alanlarında görev yapan Türkiye Taş Kömürü Kurumu (TTK) bünyesindeki tahlisiye ekipleri ve maden işçileri, 17 Ağustos ve 12 Kasım 1999 depremlerinde göçük ve enkaza, yeraltı kömür madenciliğinde kullanılan özel tahkimat metotları ile girmiştir. Ayrıca TTK tarafından doğal afetlerde yıkılmış göçük ve enkaz altında arama ve kurtarma çalışmalarını gerçekleştirmek için ekip oluşturulmuştur (TTK 2019).

Türkiye'de arama ve kurtarma çalışmalarında aktif olarak görev alan sivil toplum kuruluşları bulunmaktadır. Ülkemizde arama ve kurtarma faaliyetleri yürüten STK'lar özellikle 1999 Marmara Depreminden sonra arama ve kurtarma alanındaki eksikliklerin fark edilmesiyle birlikte yapılanmaya başlamıştır. Günümüzde arama ve kurtarma alanında faaliyetlerini yürüten STK'lardan bazıları; Arama Kurtarma Derneği (AKUT), Ayvalık Doğal Afetler Arama Kurtarma ve İlkyardım Derneği (ADAK), Anadolu Arama Kurtarma Derneği (ANAK), Edirne Arama Kurtarma Derneği (EDAK), Gönen Doğal Afetler Arama Kurtarma ve İlkyardım Derneği (GÖNDAK), Yalova Arama ve Kurtarma Derneği (K77), Operasyonel Arama ve Eğitim Derneği (K9), Türk Can Kurtarma Derneği (TÜRKCAN) ve Aydın Arama Kurtarma Yardım ve Eğitim Derneği (UMUT)'dir (URL-8 2019).

Bu STK'lar içinde önemli bir yere sahip olan, 1999 Marmara Depremi öncesinde arama kurtarma alanında tek yapılaşmaya sahip olan ve 1999 Marmara Depremi'nde de etkin ve verimli müdahalede bulunan AKUT derneğidir. AKUT resmi olarak 1996 yılında kurulmuş ve Adana-Ceyhan Depremi'nde (1998) gösterdiği yararlılıklar nedeniyle, Bakanlar Kurulu kararıyla 19 Ocak 1999'da “Kamu Yararına Dernek” statüsü almıştır. AKUT sadece ulusal değil ayrıca uluslararas1 da faaliyetlerde bulunmaktadır. Marmara Depremi'nden (1999) hemen sonra meydana gelen Yunanistan/Atina Depremi (1999), Tayvan (1999), Hindistan (2001), İran (2003), Pakistan (2005), Haiti (2010) ve Nepal (2015) depremlerinde arama ve kurtarma; 2000 yılındaki Mozambik selinde ise tıbbi destek çalışmaları gerçekleştirmiştir (AKUT 2019).

\section{Uluslararası Arama ve Kurtarma Danışma Grubu}

Uluslararası Arama ve Kurtarma Danışma Grubu (International Search and Rescue Advisory Group - INSARAG), 1985 Meksika Depremi ve 1988 Ermenistan Deprem'inde görev alan alanında uzman uluslararası USAR (Urban Search and Rescue - Kentsel Arama ve Kurtarma Ekibi) ekiplerinin destekleri ile 1991 yılında kurulmuştur (URL-9 2019). INSARAG, Birleşmiş Milletler (BM) çatısı altında faaliyet gösteren 80'den fazla ülke ve organizasyondan oluşmuş küresel bir insani ağdır. Bu insani ağ içerisinde afet yöneticileri, devlet memurları, sivil toplum kuruluşları ve USAR ekipleri görev almaktadır (URL-10 2019). INSARAG, USAR ile ilgili konuları ele almakta ve USAR ekipleri için minimum uluslararası standartlar oluşturmayı amaçlamaktadır. 
INSARAG; Birleşmiş Milletler Genel Kurulu 2002 tarihli 57/150 sayılı kararı ile kabul edilen INSARAG Yönergelerine dayalı olarak "Uluslararası Kentsel Arama ve Kurtarma Yardımının Etkinliğini ve Koordinasyonunu Güçlendirmek" kararına bağlı bir şekilde çalışmalarını sürdürmektedir. INSARAG'ın Sekretaryasını Cenevre'de İnsani İşler Koordinasyon Ofisi (UNOCHA) yürütmektedir (URL-11 2018).

INSARAG'ın temel amacı, başta depremler olmak üzere afetlerin etkisiyle meydana gelen yapı çökmesi sonucu etkilenen ülkelere yardıma giden çeşitli uluslararası USAR ekipleri arasında koordinasyonu sağlamaktır. INSARAG bu tür koordinasyonları afet öncesinde USAR ekipleri arasında işbirliği ve toplantı sağlayarak gerçekleştirmektedir. Afet öncesi USAR ekiplerince yapılan bu toplantılar yoluyla, afetler sırasında ekiplerin birlikte çalışmasını kolaylaştıracak birçok pratik anlaşmalar yapılmıştır. USAR ekiplerinin afet durumlarında birlikte nasıl çalışacakları ayrıntılı şekilde hazırlanmış bir belge olan INSARAG Kılavuzunda yer almaktadır (URL-9 2019).

Küresel düzeyde, ana görevi afet yardımı olan BM'ler kurumları, İnsani İşler Eşgüdüm Ofisi (Office for the Coordination of Humanitarian Affairs - OCHA) ve Birleşmiş Milletler Afet Değerlendirme ve Koordinasyon Ofisi (United Nations Disaster Assessment and Coordination - UNDAC)' dir. OCHA, BM'lerin afet ve acil durumlara verdiği müdahaleyi güçlendirmek ve acil durumlara etkili ve verimli müdahale sağlamak için insani yardım aktörlerini bir araya getirmekten sorumludur. Aralık 1991'de BM Genel Kurul 46/182 sayılı kararını kabul eden UNOCHA, Birleşmiş Milletlerin karmaşık acil durumlara ve doğal afetlere verdiği yanıtı güçlendirmek, aynı zamanda bu alandaki insani aktörlerin bir araya getirilmesini sağlamak ve genel faaliyet etkinliğini artırmak üzere tasarlanmıştır (URL-12 2018; Cook vd. 2018). UNDAC, acil durumlar için uluslararası acil müdahale sisteminin bir parçasıdır. Acil durumun ilk aşamasında BM'ler ve afetten etkilenen ülkelerin hükümetlerine yardım etmek için tasarlanan UNDAC ayrıca, ulusal düzeyde ve/veya acil durum sahasına gelen uluslararası yardımın eşgüdümüne yardımcı olmaktadır. UNDAC ekipleri, özellikle depremlerde uluslararası USAR ekiplerinin afet bölgesindeki yardımlarının etkin ve verimli bir şekilde yürütülmesi ve USAR ekiplerinin koordinasyonunun sağlanmasına yardımcı olmak için Yerinde Operasyonlar Koordinasyon Merkezi'nin (OSOCC) kurulmasını ve yönetilmesini sağlar (URL-13 2018).

\subsection{Türkiye'de INSARAG Çalışmaları}

Ülkemizde merkezi boyutta arama ve kurtarma faaliyetlerini ve bu faaliyetlerin koordinasyonunu sağlayan AFAD, 11 ilde kurulmuş olan Arama Kurtarma Birlikleri'nin kapasitesini geliştirerek INSARAG standartlarına çıkarılması için çalışmalarda bulunmaktadır. Bu çalışmalar kapsamında ilk olarak 2012 yılında İstanbul AFAD Arama Kurtarma Birliği Ağır Arama Kurtarma Ekibi unvanı almıştır. İstanbul AFAD INSARAG Harici Yeniden Sınıflandırmasını 20-24 Mart 2017 tarihinde (INSARAG External Reclassification - IER) başarı ile tamamlamış ve 5 yıl süreli olarak geçerli “A ğır Arama Kurtarma Ekibi” sertifikasını yeniden almıştır (URL-14 2019). Mart 2017'de Ankara AFAD Arama Kurtarma Birliği de Ağır Arama Kurtarma Ekibi unvanı almıştır (URL-15 2019).

Uluslararası Ağır Arama ve Kurtarma Ekibi unvanına sahip olan İstanbul AFAD ve Ankara AFAD'dan sonra yapılan çalışmalar ve değerlendirmelerin ardından INSARAG'dan alınan yetki çerçevesinde, Erzurum AFAD, İzmir AFAD, Afyonkarahisar AFAD, Sakarya AFAD, Bursa AFAD ve Diyarbakır AFAD Ulusal INSARAG Akreditasyon Belgesini almaya hak kazanmıştır (URL-16 2019).

INSARAG AEME (INSARAG Afrika, Avrupa, Ortadoğu AP-Asya Pasifik ve Amerikalar Bölgesi) bölgesine dahil olan Türkiye, bölgesel liderliği 2016 sonbaharında Hollanda'dan devralmıştır. Son olarak 2017 yılında Fransa (Haziran 2017) ve Türkiye (Kasım 2017), 2015 INSARAG Yönergeleri'nde belirtilen ulusal USAR ekiplerinin INSARAG standartlarını karşılamasını sağlamaya yönelik gerçekleştirilen "Ulusal Akreditasyon Süreci” (National Accreditation Process - NAP) kriterlerini sağlayan iki ülkedir (URL-17 2019; URL-18 2019).

Ayrıca 2011 yılında Orta seviye USAR unvanına hak kazanan arama ve kurtarma alanında faaliyet gösteren sivil toplum kuruluşlarımızdan olan AKUT, 20-23 Mart 2018 tarihlerinde Bulgaristan'da yapılan MODEX Egzersizi (Module Exercises- Modul Tatbikatları) ortak etkinlik çalışmalarında INSARAG rehberleri tarafından Orta USAR grubunda yeniden sınıflandırılmıştır (URL-19 2019).

\section{Kentsel Arama ve Kurtarmada Kullanılan Yöntem ve Teknikler}

Doğal afetler, terör saldırıları, kazalar gibi olaylar şehir alanlarını olumsuz etkilemektedir. Afetler yerleşim alanlarının yoğun olduğu şehirleri etkilediğinde müdahale süreci hızlı ve etkili olmalıdır. Çünkü şehirlerdeki nüfus ve yapıların yoğunluğu, deprem gibi yapıları yıkıcı etkisi fazla olan afet durumlarında etkiyi arttırıcı unsurlardır (Ochoa vd. 2007).

Afetler nedeniyle hasar görmüş ve/veya yıkılmış yapılarda arama ve kurtarma çalışmaları yapının yıkılış şekli, arazinin yapısı, afetzedeye ulaşımdaki engeller, mevcut malzeme ve personel kaynağı gibi etkenlere bağlı olarak çeşitli şekillerde yapılmaktadır. Deprem, tsunami, sel, heyelan ve terör saldırıları gibi afetler sonucu yıkılmış yapılarda enkaz altında canlı ve ölü arama ve kurtarma çalışmalarının genel olarak 5 aşaması bulunmaktadır. Bu 5 aşama şu şekildedir (FEMA 2006; Bortolin ve Ciottone 2016):

1. Aşama: Çökme alanının değerlendirilmesi, bilgi toplama ve araştırma

2.Aşama: Enkaz yüzeyindeki tüm afetzedelerin mümkün olduğunca çabuk ve güvenli bir şekilde uzaklaştırılması,

3. Aşama: Afetzedelerin erişilebilir boşluklardan aranması ve kurtarılması, 
4. Aşama: Afetzedeleri tespit etmek ve kurtarmak için belirlenmiş molozların kaldırılması,

5. Aşama: Genellikle bilinen afetzedelerin enkazdan çıkarılması sonrası genel enkaz kaldırma çalışmalarıdır.

Yıkılmış yapıların karmaşıklığı, enkaz içi boşlukların dar olması, yapı üzerinde yeni çökmelerin meydana gelmesi ve arama ve kurtarma personeli üzerinde tehdit oluşturması arama ve kurtarma çalışmalarını kısıtlayan önemli unsurlardandir.

Yapının türü, çökme düzenleri ve sarsma alternatifleri gibi çok sayıda mühendislik parametresi arama ve kurtarma faaliyetlerinin yürütülmesi sırasında gerçekleştirilecek aşamalara karar vermede önemli rol oynamaktadır. Bu faktörler, kurtarma faaliyetlerinin önceliklendirilmesi için karar vermeye katkıda bulunur ve bazı durumlarda kurtarıcıların güvenliğini sağlamada hayati öneme sahiptir. Örneğin, yapı içi rota seçimi, kısmi çökmüş bir bina altında kalan afetzedelere hızlı ve güvenli bir şekilde erişmek için çok önemlidir (Chen vd. 2011). USAR organizasyonlarının en önemli sorumluluklarından birisi de kurtarıcı personelin güvenliğinin sağlanmasıdır. Yapısal bütünlüğü bozulmuş yapılar kurtarıcı personelin güvenliğini tehdit eden en önemli unsurdur (Chen vd. 2012).

Çökmüş yapı içerisinde ve çalışma alanında kurtarma personelleri karmaşık riskler altında olup; sarsıntılar, ikincil çökmeler, tehlikeli kimyasal madde sızıntıları, gaz kaçakları ve enkaz içindeki delici kesici demir, cam, kırılmış fayans gibi unsurların yarattığı güvenlik açıklıkları meydana gelebilmektedir. Ayrıca kurtarma personelinin afetzedeye erişimindeki geçiş rotalarının dar olması ve yapı altındaki canlı ve ölülerin tespitinde arama ve kurtarma personelinin her zaman yeterli olamaması USAR çalışmalarında farklı aktörlerin yer almasını gerekli kılmaktadır. Bu nedenle yıkılmış yapılarda arama ve kurtarma çalışmaları süresince afet gönüllüleri, profesyonel arama ve kurtarma personelleri, arama ve kurtarma köpekleri, dinleme (sismik ve akustik) ve görüntülü (rescue cam) arama cihazları, robotlar ve yapılan ar-ge çalışmaları ile geliştirilen farklı teknik aletlerinden faydalanılmaktadır.

\section{1. İnsan Kaynağı ile Arama ve Kurtarma Çalışmaları}

Afetler meydana geldiğinde arama ve kurtarma çalışmaları öncelikle yerel idari birimler ve halk tarafından başlatılmalı, daha sonra merkez birimlerin desteği alınmalıdır. Afet meydana geldiği andan itibaren arama ve kurtarma çalışmaları, yakından geçenlerin yardım etmek amacıyla aceleyle bölgeye gelmesiyle birlikte hemen başlar. Dakikalar içinde yerel acil durum hizmetleri müdahalede bulunur. Arama çalışmaları, saatler içinde bölgesel veya ulusal kurtarma kaynaklarının ulaşmasıyla devam eder (INSARAG 2015).

Afetler meydana geldiğinde öncelikli olarak yerel idari birimlerin ve halkın müdahalesi oldukça önemlidir. Literatürde, büyük depremlerin ardından yıkılmış yapı molozlarının altından kurtarılan ve hayatta kalan afetzedelerin büyük çoğunluğunun arama ve kurtarma alanında uzman olmayan mahalle sakinleri, komşular, aile üyeleri, arkadaşlar veya bölgeden geçen kişiler tarafından kurtarıldığını göstermektedir. Depremlerle ilgili çok sayıda vaka çalışmasından elde edilen birikmiş verilere göre, afet sonrası hayatta kalanların \%50-95'i depremden sonraki ilk 24-48 saat içinde, bu eğitimsiz bireyler tarafından, bulabildikleri kazma, kürek, metal çubuklar gibi araçların yardımıyla kurtarılmıştır (Peleg vd. 2018). Yaşanan bazı afetlerde bölge halkının canlı olarak kurtardıkları afetzedeler dışında USAR ekipleri canlı olarak hiçbir afetzede kurtaramamıştır. Örneğin; yaklaşık 40 bin insanın öldüğü İran Bam Depremi’ne (2003) katılan 1.345 personelden oluşan 34 USAR ekibi ve 1117 kişinin öldüğü Endonezya Padang Depremi'ne (2009) katılan 688 personel ve 67 arama ve kurtarma köpeğinden oluşan 21 USAR ekibi, yerel halk tarafindan molozların altından çıkarılan afetzedelerin dışında başka hayatta kalan bulamamışlardır. Bunların dışında Pakistan Kaşmir'de 2005 yılında meydana gelen depremde 73.338 kişi ölmüş ve yalnızca 24 kişi USAR ekipleri tarafindan sağ olarak çıkartılmıştır (Peleg ve Kellermann 2012). Veriler de göstermektedir ki ilk saatlerde yerel halkın ve yerel acil durum ekiplerinin müdahalesi can kayıplarını azaltmada oldukça etkilidir.

Kentsel arama ve kurtarma çalışmalarında molozların altında sıkışan afetzedeleri canlı olarak kurtarmada en önemli ve değerli unsurlardan biriside afetin oluşumundan sonraki geçen zaman dilimidir. Daha önceki meydana gelen afet olaylarından elde edilen veriler ve deneyimler ölümlerin \%50'den fazlasının afetin oluşumunu takip eden ilk birkaç saat içinde meydana geldiğini göstermektedir. Bu nedenle afetzedelerin canlı olarak kurtarılma şansını arttırmak için arama ve kurtarma operasyonları olay meydana geldikten kısa bir süre içerinde gerçekleşmelidir (Narayanan ve Ibe 2012). Profesyonel USAR ekipleri enkaz altında mahsur kalmış hayattaki afetzedeleri bulma ve kurtarma konusunda oldukça yeteneklidir. Ancak yardım yollayacak ülkelerin ilgili karar vericilerinin, USAR ekiplerini afet bölgesine göndermeye karar vermesine kadar geçen süre ve afetin yaşandığı devletin diğer ülkelerden yardım talep edip onaylanmasına kadar geçen süre hayati öneme sahiptir. Ayrıca farklı bölgelerdeki USAR ekiplerini bir araya getirmek, afet bölgesine gönderilecek mevcut uçakları bulmak, afet lojistik malzemelerinin tedarikini sağlamak ve havaalanlarına ulaştırmak büyük zaman almaktadır. Bu zaman dilimlerine özellikle uluslararası yardımlarda bölge hakkında bilgi almak ve değerlendirme yapana kadar geçen sürede eklendiğinde USAR ekiplerinin afet bölgesine ulaşım süresi 24 ile 48 saat veya daha fazla zaman alabilmektedir. Şiddetli bir deprem sonrası, bir ülkenin ihtiyacı olan eğitimli kurtarma görevlilerinin sayısı, bir ülkenin eğitimli ve donanımlı tutabileceği USAR ekiplerinin sayısından çok daha fazla olmaktadır (Peleg 2015). Bu nedenlerle USAR ekipleri bölgeye ulaşana kadar geçen sürede yereldeki yanıt büyük öneme sahiptir. Bunun en önemli örneklerinden biri 1988 Ermenistan depremidir. 1988 Ermenistan'da meydana gelen depremde ilk 24 saat içerisinde çoğunlukla ağır ekipman kullanılmadan afetzedelerin \%89’u yerel müdahale ile kurtarılmıştır (Noji vd. 1990). 
Ancak yerel acil durum ekiplerinin ve bölge halkının müdahaleleri her zaman yeterli olmamaktadır. Afetin meydana geldiği andan itibaren arama kurtarma çalışmalarına çok sayıda mahalle afet gönüllüleri, STK'lara ait profesyonel arama ve kurtarma ekipleri ile arama ve kurtarma alanında herhangi bir eğitim almamış bölge halkı destek vermektedir. Fakat olaydan etkilenen yerel halkın her birinin birer afetzede niteliği taşıdığı unutulmamalıdır. Yerelde müdahalede bulunanlar olayın ilk şokunun ardından yakınlarının can sağlığını korumaya ve akabinde de ihtiyaçlarını karşılamaya çalışacaklardır. Bu nedenle yerel halk da bir süre sonra yetersiz kalmaya başlayacaktır. Bu nedenle yereldeki ilk müdahale kadar USAR ekiplerinin de önemi oldukça büyüktür.

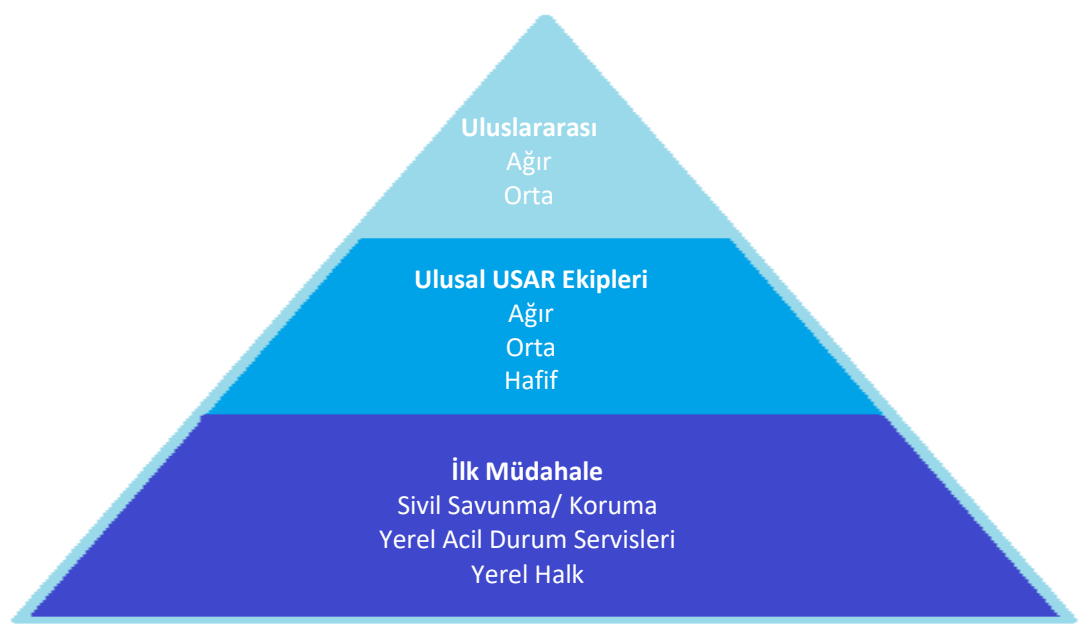

\section{Şekil 2: INSARAG USAR Müdahale Çerçevesi (Yazarlar tarafından INSARAG USAR Müdahale Çerçevesi'ne (INSARAG 2015) bağlı kalınarak çevrilmiştir)}

Şekil 2'de görüldüğü gibi INSARAG afetlerde arama ve kurtarma ile ilgili öncelikle afet bölgesindeki yerel halkın, yerel acil durum servislerinin ve sivil savunmanın müdahalesini öngörmektedir. Yerel ekiplerin yetersiz kaldığ durumlarda bir üst basamakta hafif - orta - ağır arama ve kurtarma niteliğine sahip ulusal USAR ekiplerinin devreye girmesi gerektiğini belirtmektedir. Ulusal USAR ekiplerinin de yetersiz kaldığı durumlarda ise orta ve ağır arama ve kurtarma niteliğine sahip uluslararası USAR ekiplerinin devreye girmesi gerektiği vurgulanmaktadır.

\subsection{Köpekle Arama ve Kurtarma Çalışmaları}

Köpeklerin arama ve kurtarmaya yönelik kullanımı, İsviçre'de Alplerde rahipler tarafından kar altında gömülü insanları bulmak amacıyla 1600'lerde başlamıştır. Ayrıca 1. Dünya Savaşı'nda ve Londra Saldırıları'nda gömülü insanları bulmak ve Lockerbie'de 1988 yılında bomba nedeniyle meydana gelen uçak kazası gibi afet durumlarında da kullanılmıştır. Köpekler, havadaki insan kokusunu algılamak için akut koku duyularını kullanmak üzere eğitilmiştir. Köpekler sahip olduğu 200 milyondan fazla koku reseptörü sayesinde havadaki insan kokusu izlerini tespit etmekte ve kokunun en yoğun olduğu kaynağa kadar takip edebilmektedir. Köpek ve eğiticisi/sürücüsü oldukça iyi bir ekip oluşturmaktadır (SARDA 2019)

Yalnızca canlı arayan köpekler, yalnızca insan kalıntılarını arayan köpekler ve her ikisini de aramak için çapraz eğitimli köpekler olmak üzere üç tür arama köpeği bulunmaktadır. Her tür arama köpeği, eğiticisine hedef kokularını belirlediklerini bildirmek için farklı davranışlara sahip olmalıdır. Bu "nihai tepki davranışı" olarak bilinmektedir (Alexander vd. 2011).

Arama ve kurtarma çalışmalarında köpekler iyi birer işbirlikçidir. Çalışmalar arama ve kurtarma köpeklerinin USAR ekipleri için oldukça değerli bir işbirlikçi olduğunu ancak USAR ekiplerinin, arama ve kurtarma köpeklerinden her zaman \%100 yeterlilikte performans göstermesinin beklenmemesi gerektiğini göstermektedir (Greatbatch vd. 2015).

Türkiye'de daha çok askeri amaçlarla kullanılan köpekler 1990'lardan itibaren arama ve kurtarma faaliyetlerinde de kullanılmaya başlanmıştır. Ülkemizde doğal afetlerde arama ve kurtarma köpeklerinin kullanılmasına ilişkin ilk ciddi çalışmalar 1999 Gölcük Depremi ile başlamıştır. Bu tarih ülkemiz için bir milat olup, bugün Türkiye'de resmi ve özel kurumlar, sivil toplum örgütleri ve ferdi gönüllülerden oluşan birçok köpekli arama timi bulunmaktadır (URL-20 2019).

Köpekle arama ve kurtarma çalışmaları, enkaz altındaki afetzedelerin yerinin tespitinde etkili bir yöntemdir. Köpekle arama kurtarmada genellikle köpek üzerine yerleştirilen dinleme ve görüntülü arama cihazlarından da faydalanılır. Bir köpek ekibi; köpek ve eğiticisinden oluşur. Köpekler, işitme ve koku alma duyuları ile enkaz altında mahsur kalmış afetzedelerin yerini tespit etmek için kullanılmaktadır (FEMA 2004). 
Yurtdışında, arama ve kurtarma alanında kullanılacak köpeklerin birçok ulusal, bölgesel veya eyalet kuruluşlarının biri tarafından sertifikalandırılması konusuna önem verilmekte olup köpeklerin sertifikalandırılması şiddetle tavsiye edilmektedir (Alexander vd. 2011). Kentsel arama ve kurtarmada kullanılan köpeklerin genel özellikleri şunlardır;

- Özel eğitimli köpekler, fiziksel arama sonucu yerleri tespit edilen afetzedelerin kurtarılması ve daha zor şartlardaki afetzedelerin yerlerinin tespit edilmesinde önemli katkı sağlar,

- Köpekler güvenli olmayan veya personelin giremeyeceği dar alanlara da girebilir. Köpeğin tepki verdiği bölge işaretlenir ve cihazlarla dinleme yapılarak daha net bilgilere ulaşılmaya çalışılır,

- Çok hızlı ve seri bir arama yapabilirler,

- USAR ekiplerine afetzedenin yerinin tespitinde doğru yönlendirme yapabilirler,

- İkinci çökmelere sebep olmayacak kadar hafiftirler,

- Açık arazide yapılan aramalarda mükemmel sonuçlar verirler (Ankara İtfaiyesi 2012; İstanbul İtfaiyesi 2014).

- Köpeklere takılacak termal ve video kameralar ile akustik cihazlardan faydalanılarak enkaz altında daha iyi inceleme yapılabilir. Yapılan incelemeler ile enkaz altında kalan bilinçli ve bilinçsiz afetzedelerin yerlerinin tespiti yapılabilir. Bu sayede afetzedeler hakkında daha doğru ve net veriler elde edilir. Ayrıca afetzedenin çıkarılmasının uzun zaman alacağı durumlarda köpeğin afetzedelere su, yiyecek vb. malzemeleri taşıması da mümkün olabilmektedir (FEMA 2004).

Arama ve kurtarma çalışmalarında kullanılan köpeklerin avantajları gibi bazı dezavantajları da bulunmaktadır. Köpek kullanmanın dezavantajları arasında köpekler arasındaki performans farklılıkları yer almaktadır. Nem ve sıcaklık gibi çevresel koşullar ile işlemin uzunluğu arama köpeklerinin kabiliyetlerini olumsuz etkileyebilir. Ayrıca koku kaynağının üzerindeki molozlar arttıkça köpeklerin yer belirlemesi zorlaşmaktadır (FEMA 2004). İyi eğitilmemiş köpekler insanın bulunmadığı noktalarda uyarı verip USAR ekiplerinin yanlış bölgede arama yapmasına neden olabilmektedirler (Greatbatch vd. 2015). Köpeğe verilecek olan temel itaat ve çeviklik eğitimlerinin köpeğin belli yaş döneminde verilmesi gerektiği aksi taktirde köpeklerin arama performanslarında büyük farklılıklar oluştuğu belirtilmektedir. Bununla birlikte köpekler olgunlaştıkça boyutu artmakta ve fiziksel olarak kontrol edilmesi zorlaşmaktadır. Olgunlaştıkça daha büyük ve fiziksel olarak daha güçlü hale gelen köpekleri itaat komutlarına uyumu öğretmek için, zincir, kısma bilezikleri ve / veya elektronik yakalar gibi zorlayıcı ekipmanlara başvurma durumları söz konusu olmaktadır. Zorlama ile eğitilmiş köpeklerde performans düşük olmakla birlikte köpek stres altına girebilmektedir (Alexander vd. 2011).

Tablo1: Kentsel Arama ve Kurtarmada Görev Alabilecek Köpekli Arama Timleri*

\begin{tabular}{|c|c|c|c|c|c|c|}
\hline No & $\begin{array}{l}\text { Bağlı Olduğu } \\
\text { Kurum }\end{array}$ & Köpeğin Cinsi & $\begin{array}{l}\text { Sertifika } \\
\text { Geçerlilik Süresi }\end{array}$ & Cinsiyet & Doğum Yılı & Bulunduğu İl \\
\hline 1 & AFAD & Belgian Malinois & 03.11 .2019 & Erkek & 18.05 .2012 & Adana \\
\hline 2 & AFAD & Alman Sable & 16.10 .2020 & Dişi & 01.08 .2014 & Adana \\
\hline 3 & AFAD & Labrador-Mix & 03.11 .2019 & Dişi & 20.02.2014 & Afyonkarahisar \\
\hline 4 & AFAD & Dutch Sthepherd & 03.11 .2019 & Dişi & 21.07.2015 & Afyonkarahisar \\
\hline 5 & AFAD & Labrodar Retriever & 03.11 .2019 & Erkek & 05.10 .2014 & Afyonkarahisar \\
\hline 6 & AFAD & Belgian Malinois & 16.10 .2020 & Dişi & 30.04 .2016 & Afyonkarahisar \\
\hline 7 & AFAD & Belgian Malinois & 16.10 .2020 & Erkek & 12.01 .2016 & Afyonkarahisar \\
\hline 8 & AFAD & Golden Retriever & 16.10 .2020 & Dişi & 08.08 .2016 & Afyonkarahisar \\
\hline 9 & AFAD & Alman Sable-Mix & 03.11 .2019 & Dişi & 25.03 .2011 & Ankara \\
\hline 10 & AFAD & Alman Sable & 16.10 .2020 & Erkek & 14.03.2016 & Ankara \\
\hline 11 & AFAD & Belgian Malinois & 16.10 .2020 & Dişi & 13.02 .2016 & Ankara \\
\hline 12 & İtfaiye & Mix & 16.10 .2020 & Dişi & 01.10 .2013 & Ankara \\
\hline 13 & AKUT & Belgian Malinois & 03.11 .2019 & Erkek & 22.10 .2013 & Aydın \\
\hline 14 & AKUT & Border Collie & 16.10.2020 & Dişi & 03.09.2012 & Aydın \\
\hline 15 & AFAD & Belgian Malinois & 16.10 .2020 & Erkek & 07.05 .2016 & Bursa \\
\hline 16 & İHH & Belgian Malinois & 16.10.2020 & Dişi & 24.03 .2016 & Bursa \\
\hline 17 & AFAD & Belgian Malinois & 03.11 .2019 & Erkek & 11.11.2011 & İstanbul \\
\hline 18 & AFAD & Golden Retriever & 03.11 .2019 & Erkek & 01.04 .2015 & İstanbul \\
\hline 19 & AFAD & Belgian Malinois & 03.11 .2019 & Erkek & 25.03 .2014 & İstanbul \\
\hline 20 & AFAD & Belgian Malinois & 03.11 .2019 & Erkek & 25.11 .2014 & İstanbul \\
\hline 21 & GEA & Labrador Retriever & 16.10 .2020 & Erkek & 01.07.2012 & İstanbul \\
\hline 22 & İtfaiye & Labrador Retriever & 16.10.2020 & Erkek & 17.02.2014 & İstanbul \\
\hline 23 & Reflex & Golden Retriever & 03.11 .2019 & Dişi & 01.08 .2012 & İstanbul \\
\hline 24 & AKUT & Belgian Malinois & 03.11 .2019 & Erkek & 09.10 .2011 & İzmir \\
\hline 25 & AKUT & Border Coli & 03.11 .2019 & Erkek & 26.05 .2014 & İzmir \\
\hline 26 & İtfaiye & Belgian Malinois & 03.11 .2019 & Erkek & 23.09.2015 & İzmir \\
\hline 27 & AFAD & Belgian Malinois & 03.11 .2019 & Dişi & 11.11.2011 & Sakarya \\
\hline 28 & AFAD & Belgian Malinois & 16.10 .2020 & Dişi & 25.11 .2016 & Sakarya \\
\hline 29 & AFAD & Belgian Malinois & 03.11 .2019 & Dişi & 17.10.2010 & Samsun \\
\hline 30 & AFAD & Belgian Malinois & 16.10.2020 & Dişi & 04.05 .2016 & Samsun \\
\hline 31 & AFAD & Alman Sable & 03.11 .2019 & Dişi & 01.07.2014 & Van \\
\hline 32 & AFAD & Golden Retriever & 16.10.2020 & Erkek & 01.02 .2016 & Van \\
\hline
\end{tabular}


Tablo 1 ve 2'de görüldüğü gibi AFAD koordinasyonunda yapılan köpekli arama timi sınavlarına katılan köpeklerden arama ve kurtarma çalışmalarında görev alabilecek ve görev süresi dolmuş veya görev yeterlilik belgesi olmayan köpeklere ait bilgiler verilmiştir. Tablo 1'de verildiği gibi AFAD, İtfaiye, STK ve gönüllü kişilere ait kentsel arama ve kurtarma çalışmalarında görev alabilecek nitelikte toplam 32 adet köpek mevcuttur. Mevcut köpeklerin 22'si AFAD'a, 3'ü farklı itfaiye birimlerine, 7'si STK'lar ve farklı kurumlara aittir. Yine farklı kurum, kuruluş, STK ve gönüllü kişilere ait sertifika süresi dolan veya görev yeterlilik sınavını geçemeyen 28 köpek (Tablo 2) mevcuttur.

Tablo 2: Görev Yeterlilik Belgesi Olmayan veya Süresi Dolmuş Köpekli Arama Timleri*

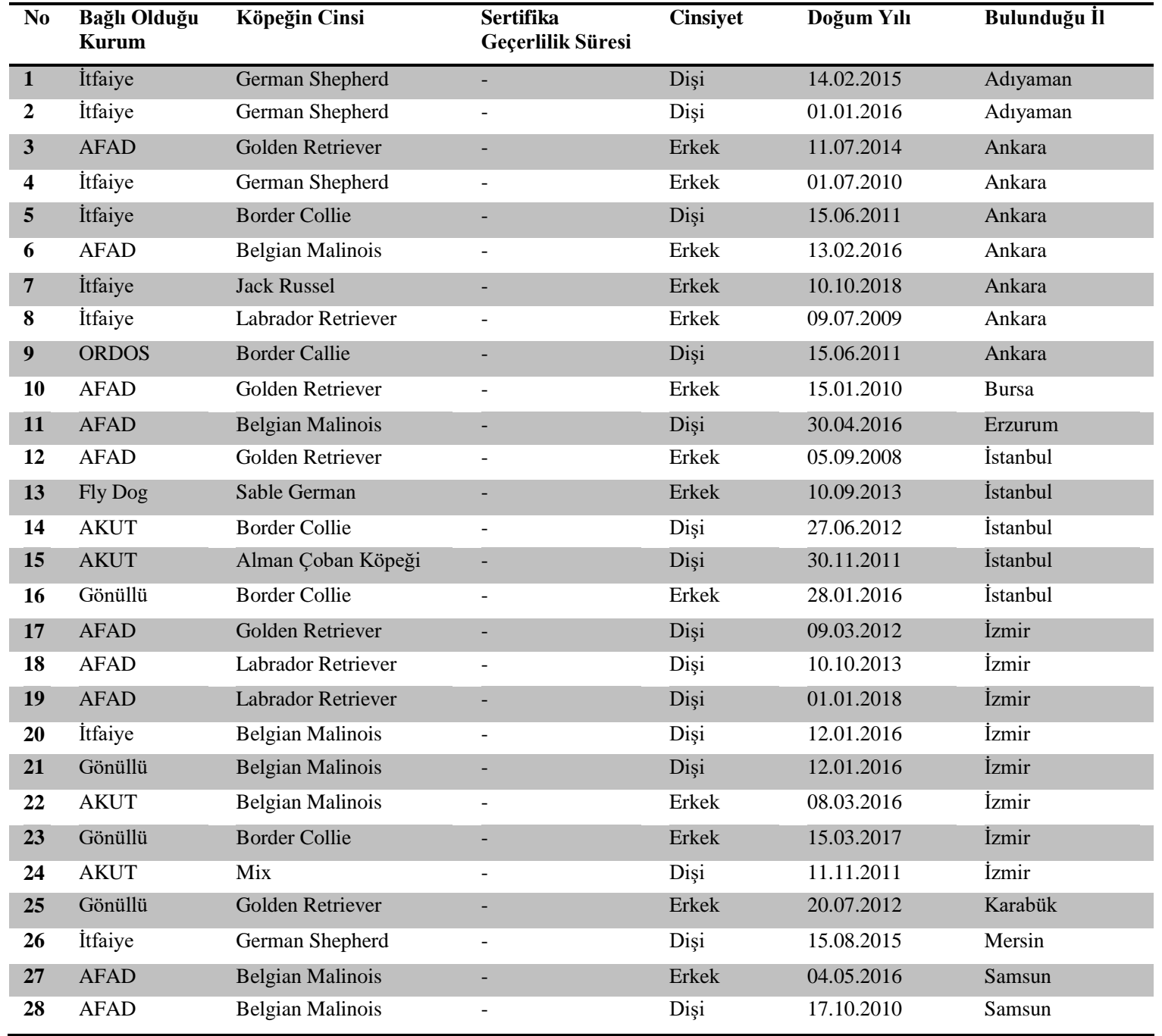

* Arama ve kurtarma ile ilgili Kentsel Arama ve Kurtarmada Görev Alabilecek Köpekli Arama Timleri ve Görev Yeterlilik Belgesi

Olmayan veya Süresi Dolmuş Köpekli Arama Timleri verileri AFAD kurumundan resmi izinle alınmış ve kurum onayı ile kullanılmıştır.

\subsection{Robot Destekli Arama ve Kurtarma Sistemleri}

Deprem ve terör saldırıları gibi olaylarda kurtarma faaliyetlerinde, çökmüş yapıları içeren herhangi bir afet bölgesinde riskli alanlara daha fazla erişim için robotlara oldukça ihtiyaç duyulmaktadır. Teknolojideki ve uzaktan kontrol endüstrisindeki gelişmeler ile birlikte küçük robotik mikro-gezici sistemlerinin de gelişmesiyle bu sistemlerin kentsel arama ve kurtarma için önemli rollerde kullanılabileceği düşünülmektedir (Blitch 1996). Özellikle sensör teknolojisindeki son gelişmeler, kablosuz iletişim, robotik sistemler, bilgisayar ve görüntülü-işitsel teknoloji ile afetzedelerin yerlerini tespit etmek, onları bulunduğu yerden hızlı bir şekilde kurtarmak ve gerekli yardımları yapmak için kullanılabilecek tekniklerin geliştirilmesine yol açıฺștır (Narayanan ve Ibe 2012; Murphy 2000).

Çökmüş yapılar sadece afetzedeler ve aileleri için değil, aynı zamanda son derece karmaşık, tehlikeli ve sinir bozucu bir görev ortamı ile karşı karşıya kalan profesyonel kurtarma personeli için de bir endişe uyandırmaktadır. Ayrıca, çöken binanın bazı bölgeleri kurtarıcılar için erişilemezdir. Bu koşullarda, arama ve kurtarmayı gerçekleştirmek için, çöken yapıda kentsel arama ve kurtarma mobil robotları kullanılabilir (Blitch 1996; Ye vd. 2006). Kurtarma robotları, afetlerde durum hakkında gerçek zamanlı video ve diğer duyusal veriler sağlamaktadır (Murphy vd. 2008). 
Arama ve kurtarma robotları, kurtarma operasyonlarının verimliliğini artırmakla birlikte aynı zamanda kurtarıcılarında yaralanma ve ölüm riskini en aza indirmektedir. Robotlar kurtarma ekiplerine yardımcı olmakla beraber kurtarma görevlilerinin gerçekleştireceği tehlikeli görevleri üstlenebilmektedir (Jinguo vd. 2007). Arama ve kurtarma görevindeki güvenlik, hızlılık, ağır yük ve çevre karmaşıklığı gibi konulara karşı daha başarılı olmak için araştırmacılar günümüzde birçok robot geliştirmiştir (Ye vd. 2006). Günümüzde arama ve kurtarmada kullanılan bu robotlar; Su Samuru İnsansız Yüzey Aracı (The Otter Unmanned Surface Vehicle - USV), İnsansız Su Altı Araçları (Unmanned Underwater Vehicles - UUV), İnsansız Kara Aracı (An unmanned ground vehicle - UGV) ve İnsansız Hava Araçları (Unmanned Aerial Vehicles - UAV)'dir (Murphy vd. 2008).

Robotların arama ve kurtarmada kullanımı için ilk önemli çalışmalar 1995 yılında Amerika Birleşik Devletleri (ABD) Oklahoma Bombalaması ve Büyük Kobe Hanshin Depremleri’ndeki can kayıplarından sonra başlamıştır (Ko ve Lau 2009; Murphy vd. 2008). Kentsel arama ve kurtarma robotlarının ilk belgelenmiş kullanımı 11 Eylül 2001 Dünya Ticaret Merkezi (WTC) terör saldırıları sonrası gerçekleştirilmiştir (Ko ve Lau 2009). 2006 itibariyle, arama ve kurtarma robotları ABD'de; Katrina, Rita ve Wilma kasırgaları ve Dünya Ticaret Merkezi saldırısı olmak üzere dört afette kullanılmış olup, halen kullanılmaya ve yeni robotlar üretilmeye devam edilmektedir (Murphy vd. 2008). Özellikle 11 Eylül saldırılarından sonra birçok ülke terörle mücadelede görev alan robotlarının yanı sıra afetlerde görev yapmaları için arama ve kurtarma robotları geliştirmeye başlamıştır (Jinguo vd. 2007). Robotlar sadece büyük ölçekli olaylarda değil ayrıca küçük ölçekli kazalarda da kullanılmaktadır. Örneğin ABD ve Japonya'da bulunan bazı itfaiyelerde suda arama için küçük su altı robotları kullanılmaktadır. ABD'de maden patlamalarında zemin robotları kullanılmaktadır (Murphy vd. 2008).

Geçmişte arama ve kurtarma köpekleri, akustik sinyaller ve insanla fiziksel arama ve kurtarma afetzedelerin yerlerini tespit etmek için birincil yöntem olmuştur. Kullanılan bu yöntemler arama ve kurtarma personellerinin ve köpeklerinin enkaz altında afetzedeye erişebildiği durumlarda işe yaramıştır. Ayrıca afet bölgesinde mahsur kalan çok sayıdaki afetzede için yeterli miktarda insan ve köpek yardımı söz konusu olamamaktadır. Kurtarma köpekleri arama ve kurtarmada görev alan insanların zarar görme riskini azaltmaya yardımcı olabilmekte ve moloz altında insanlardan daha küçük boşluklara girebilmektedir. Ancak köpekler bir video kamera veya yapısal değerlendirme ekipmanı gibi hafif mobil robotların yerini alamamaktadırlar. Hafif mobil robotlar, kentsel arama ve kurtarma çalışmaları süresince yıkılmış yapılarda arama ve kurtarma personelleri ve köpeklerine yönelik zarar görme riskini azaltırken birçok fayda sağlayabilmektedir (Narayanan ve Ibe 2012; Murphy 2000).

Mobil robotlar binanın içine, suyun altına girip herhangi bir afetzede olup olmadığını tespit edebilecek ve ardından USAR ekip üyelerine kurtarma için sinyal gönderebilecek faydalı araçlardır. Mobil robot kullanmanın amacı, afetzedelerin yerini belirlemek ve afetzedelere ulaşmaya çalışan kurtarma ekibini doğru yere yönlendirmektir. Robotların boyutu küçük bir cihazdan hareketli vince kadar çok farklı şekilde olabilmektedir. Robotlar, kimyasal tesisler ve insanların ulaşamadığı nükleer reaktörler gibi tehlikeli yerlerde de kullanılabilmesi açısından avantaj sağlamaktadır (Narayanan ve Ibe 2012).

Arama ve kurtarmada kullanılan bazı robotların genel özellikleri şu şekilde özetlenebilir;

- Normalde insanı yorabilen bir titizlik düzeyi ile hayatta kalanlar için detaylı araştırmalar yapar,

- Molozlara özel sensör yerleştirir ve konumlandırır,

- Yapısal hasarı değerlendirmek için görsel ve sismik veriler toplar,

- Radyo vericileri, küçük miktarlarda yiyecek, içecek ve ilaç gibi önemli malzemeleri sıkışmış afetzedeye ulaştırır,

- Tibbi destek aletlerinin yerleştirilmesine rehberlik eder,

- Kurtarma esnasında arama ve kurtarma personelinin afetzedenin koluna veya bacağına zarar vermesini önlemek için uzuvların yerini belirler (Murphy 2000).

- Hizlı arama yapar,

- Sert zeminde yüksek hareket kabiliyetine sahiptir,

- Üst katlara tırmanabilir ve boru, mağara gibi dar alanlardan geçebilir (Ye vd. 2006).

Arama ve kurtarma için çok sayıda robot mevcuttur. Bu robotların avantajları oldukça fazla olmakla birlikte bazı dezavantajları da söz konusu olmaktadır. Bazı robotlar enkaz içinde dikey ve yatay zeminlerde ilerleyememektedir. Bazıları ise sola ve sağa dönmede başarılı değildirler. Büyük paletli bir robotun kafa kısmı tavana çarpar ve robot enkazda sıkışabilir. Enkaz içinde kontrolünü kaybederek yuvarlanan robotu yönetmek zor olmaktadır ve robot yuvarlandığında ya da bir yere sıkıştığında robotu kurtarmak için ayrı bir kurtarma çalışma yürütülmesi gereklidir. Bazı robotlar boyutları nedeniyle, molozların mevcut olduğu eğimli ve çukurlu zemin üzerinde çalışabilirliği düşüktür. Ayrıca büyük boyutlu robotlar dar alanlı enkaz içine giremezken, küçük boyutlu robotlar ise dikey zeminlerde hareket kısıtlılı̆̆ yaşayabilmektedir (Osuka ve Kitajima 2003).

\subsection{Dinleme ve Görüntülü Cihazlar ile Arama ve Kurtarma Çalışmaları}

Geliştirilen sismik/akustik dinleme cihazları arama ve kurtarma çalışmalarına katkı sağlayan çok ileri teknolojik özelliklere sahiptir. Bu cihazlar ile göçük altındaki boşluklarda, şaftlarda ve aralıklarda kalmış yaşayan kişilerin ürettiği sinyaller görüntülü ve sesli olarak algılamak mümkün olmaktadır (İstanbul İtfaiyesi 2014). Katı madde ile iletilen ses sensörler vasıtası ile alınmaktadır. Sensörler duvar, tavan, taban, kriş gibi katı maddeler üzerine yerleştirilmelidir. Özellikle sıhhi tesisat boruları sesi çok uzak mesafelere taşırlar (İstanbul İtfaiyesi 2014). 
Oldukça hassas olan sismik-akustik sensörler, hayatta kalan afetzedelerin dokunma, tırmalama, vurma sesleri ile hayatın en ufak bir işaretini bile algılayabilmektedir (URL-21 2018). Akustik cihazlar aynı zamanda afetzedeleri tespit etmek için kullanılmaktadır. Ancak gürültülü arama ortamlarında kullanımları oldukça sınırlıdır. Bir başka dezavantaj ise, bu tür cihazların bilinçsiz afetzedeleri tespit edememesidir (Bloch vd. 2016).

Aynı zamanda uzayabilen kameralar ile hem görsel hem işitsel olarak enkaz altından veri alınabilir. Küçük çaplı arama kameraları gibi elektronik cihazlar, enkaz altında sıkışmış afetzedeler hakkında bilgi sağlamak için boşluk alanlarına girmek için kullanılmaktadır. Ancak bu küçük çaplı arama kameraları çoğu zaman toz veya duman nedeniyle görüş alanı sinırlamalarına maruz kalmaktadır (Bloch vd. 2016).

\section{Sonuç}

Bütünleşik afet yönetimi kapsamında risk ve kriz yönetiminin tüm basamakları, kayıpları azaltmak ve dirençli bir toplum yaratmak için önem arz etmektedir. Risk yönetimi mümkün oldukça başarıyla gerçekleştirilmelidir. Risk yönetiminin başarısı kriz yönetiminin de başarısını mutlaka etkileyecektir. Risk yönetimi ne kadar iyi yapılırsa yapılsın şiddetli bir şekilde meydana gelen bazı afetlerin yıkıcılığının önüne geçmek şu anki teknolojiyle neredeyse imkânsızıdır. Özellikle deprem, baraj, köprü ve tünel çökmeleri ve terör saldırıları gibi yapısal çökmelerin meydana geldiği afetlerde altın saatler olarak da adlandırılan ilk saatlerde yapılan arama ve kurtarma çalışmaları enkaz altında kalmış afetzedelerin sağ olarak kurtarılması açısından önem arz etmektedir. Bu nedenle bütünleşik afet yönetiminin önemli bir aşaması olan müdahale aşaması kayıpları en aza indirmek için oldukça önemlidir.

Müdahale aşamasının basamaklarından biri olan arama ve kurtarma, afetzedelerin yerinin tespiti ve kurtarılmasını sağlar. Bu amaçla arama ve kurtarma çalışmalarında farklı birçok aktör ve yöntem kullanılmaktadır. Kentsel arama ve kurtarma çalışmalarında profesyonel ekipler, yerel halk, köpekler, robotlar, sismik ve görüntülü arama cihazları gibi aktörlerde rol almaktadır. Bu aktörlerin her biri farklı görevler ile kentsel arama ve kurtarma çalışmalarında etkili ve verimli olarak kullanılmakla beraber çalışmaların bütünsel olarak yürütülmesini sağlama ve birbirini tamamlama rolleri vardır. Afet meydana geldikten sonra ilk olarak yerel acil durum birimlerinin ve yerel halkın bir müdahalesi söz konusu olur ve dünya genelinde ilk olarak yerel birimlerin ve halkın müdahalesi önerilmektedir. Olayın sıcaklığıyla afet bölgesindeki yerel halk arama ve kurtarma çalışmalarına başlarlar. Ancak arama ve kurtarma çalışmasına başlayan bu kişiler de birer afetzede olup, arama ve kurtarmada genellikle ailelerine ve yakınlarına ulaşmayı amaç edinirler. Yerelde bulunan acil durum ekipleri çalışanları da afetzede olduklarından etkili bir müdahalede bulunamayabilirler. Bu nedenle yerelde müdahale oldukça önemli olmakla beraber yerel müdahalenin yetersiz kaldığı durumlarda en kısa sürede afet bölgesine profesyonel ve gönüllü kentsel arama ve kurtarma ekiplerinin intikal etmesi gerekmektedir. Profesyonel ekipler olayın şiddetine bağlı olarak afetzede sayısı karşısında yetersiz kalabileceğinden arama ve kurtarma faaliyetlerinde gönüllülük de oldukça önemli bir yer tutmaktadır. Ulusal kentsel arama ve kurtarma ekiplerinin de yetersiz kaldığı durumlarda uluslararası kentsel arama ve kurtarma ekipleri devreye girmektedir. Bu basamaklar INSARAG tarafindan oluşturulmuş ve arama ve kurtarma ekiplerini sınıflandırarak afet durumlarında ihtiyaç halinde hafif - orta - ağır arama ve kurtarma niteliğine sahip USAR ekiplerinin müdahalesi söz konusu olmaktadır. Günümüzde arama ve kurtarma çalışmalarında insan faktörünün önemi daha çok anlaşılmakta olup, INSARAG tarafindan sertifikasyon sağlanan arama ve kurtarma ekipleri ülkemizde ve dünyada gittikçe artmaktadır. Ayrıca ülkemizde çoğu zaman göz ardı edilen arama ve kurtarma konusunda gönüllülük konusu kamu kurumları ve sivil toplum kuruluşları tarafindan desteklenmelidir. Çok sayıda afete sık sık maruz kalan bir ülke olarak arama ve kurtarma da dâhil olmak üzere afetler konusunda sivil toplum kuruluşları ve gönüllü çalışmaları konusunda oldukça eksik bir konumda bulunmakta ve bu konularda çalışmalar yapmamız gerekmektedir.

İnsan gücünün yanında köpekler de canlı ve ölü aramada kullanılmaktadır. Köpekler keskin koku alma duyuları sayesinde canlı ve ölü insan bulabilme yeteneğine sahiptirler. Hafif olduklarından dolayı enkazlar da ikincil çökmelerin meydana gelmesine sebep olmayarak yer tespiti sağlamaktadırlar. Ayrıca insanların giremediği dar alanlara girerek afetzedelere su -gıda gibi gerekli malzemeleri ulaştırabilirler. Köpeklerin arama ve kurtarma başarısı yüksek olmakla birlikte yüzde yüz başarılı olmamaktadırlar. Ülkemizde çoğunluğu AFAD bünyesinde olmak üzere bazı kamu kurumları ve STK'lar bünyesinde canlı ve ölü arama köpeği bulunmaktadır. Ancak bu sayılar yaşadığımız ülkenin afet durumları göz önüne alındığında yetersiz kalmaktadır. Bu nedenle Türkiye'deki arama ve kurtarmada kullanılacak köpek ve eğitmen sayısının arttırılması gerekmektedir.

Teknolojik gelişmelerle birlikte arama ve kurtarma alanında da çok sayıda robot, dinleme ve görüntülü arama cihazı kullanılmaya başlanmıştır. Dinleme ve görüntülü arama cihazları ile robotların; çok küçük cihazdan çok büyük bir vinç büyüklügüne kadar üretilmiş çeşitli alternatifleri mevcuttur. Robotların enkaz altında afetzede arama ve kimyasal maddelerin bulunduğu tehlikeli alanlara girebilme gibi özellikleri nedeniyle oldukça avantajlı arama ve kurtarma araçlarıdır. Günümüzde robotik cihazların geliştirilmesi devam etmekle birlikte kullanımı da yaygınlaşmaktadır. Özellikle Japonya ve ABD arama ve kurtarma robot teknolojilerini kullanma ve geliştirme üzerine ciddi çalışmalar yürütmektedir. Bu çalışmalar Japonya'da International Rescue System Institute'de ve ABD'de Center for Robot-Assisted Search and Rescue'de sürdürülmektedir (Murphy vd. 2008). 
Yaşadı̆̆ımız coğrafya nedeniyle her zaman afetlere maruz kalan bir konumda olan ülkemizde bütünleşik afet yönetiminin başarısı can kaybının en aza indirilmesi açısından oldukça önem taşımaktadır. Afet meydana geldikten sonra müdahale aşamasında altın saatlerde gerçekleştirilen arama ve kurtarma çalışmaları afetzedelerin mahsur kaldıkları yerden kurtarılmaları sağlamakta ve can kayıplarını engellemektedir. Can kaybını en aza indirmek için arama ve kurtarma çalışmaları hemen başlamalıdır. USAR ekipleri arama ve kurtarma çalışmalarında tek başına yeterli olamayabileceğinden dolayı kurtarma çalışmalarında gönüllülerin de desteği alınmalıdır. Arama ve kurtarma çalışmaları için nitelikli personel sayısının arttırılması ve gerekli teçhizatın temin edilmesi gerekmektedir. Ayrıca kentsel arama ve kurtarma çalıșmalarına büyük katkı sağlayan eğitimli ve sertifikalı köpekler ile köpek eğitici/sürücülerinin de sayısının arttırılması ülkemiz açısından önem taşımaktadır. Tüm bunların yanında teknolojik gelişmelerin arama ve kurtarma alanına kazandırdığı robotlar, dinleme ve görüntülü arama cihazlarının da arama ve kurtarma envanterine eklenmesi müdahale aşamasında arama ve kurtarma çalışmalarına büyük katkı sağlayacaktır. Ayrıca afetlere maruz kalma oranı yüksek olan bir ülke olarak arama ve kurtarma ile ilgili robot, görüntülü ve dinleme cihazlarının geliştirilmesine yönelik Ar-Ge çalışmalarının arttırılması gerekmektedir.

\section{Kaynaklar}

Akay A., (2017), Türkiye’de Afet Yönetimi Politikaları, Afet Yönetimi-II'nin İçinde (Özmen B. Ed.), Anadolu Üniversitesi Yayınları, ss. $212-248$

AKUT, (2019), AKUT Tarihçe, https://www.akut.org.tr/tarihce, [Erişim 04 Ocak 2019].

Alexander M.B., Friend T., Haug L., (2011), Obedience training effects on search dog performance, Applied Animal Behaviour Science 132(3-4), 152-159.

Ankara İtfaiyesi, (2012), Kentsel Arama Kurtarma, Ankara İtfaiyesi Yayınları Hizmet İçi Eğitim Serisi 11, Polen Yayın Evi, Temmuz 2012.

Blitch J.G., (1996), Artificial intelligence technologies for robot assisted urban search and rescue, Expert Systems with Applications 11(2), 109-124.

Bloch T., Sacks R., Rabinovitch O., (2016), Interior models of earthquake damaged buildings for search and rescue, Advanced Engineering Informatics, 30(1), 65-76.

Bortolin M., Ciottone G.R., (2016), Urban Search and Rescue, Ciottone's Disaster Medicine (2nd Edition)'in İçinde (Ciottone G.R., Ed.), Elsevier, ss.329-333.

Chen A.Y., Pena-Mora F., Mehta S.J., Foltz S., Plans A.P., Brauer B.R., Nacheman S., (2011), Equipment distribution for structural stabilization and civilian rescue, International Journal of Information Systems for Crisis Response and Management (IJISCRAM), 3(1), 19-31.

Chen A.Y., Pena-Mora F., Plans A.P., Mehta S.J., Aziz Z., (2012), Supporting urban search and rescue with digital assessments of structures and requests of response resources, Advanced Engineering Informatics, 26, 833-84.

CRED, (2018), Economic loses, poverty \& disasters 1998-2017, https://www.unisdr.org/files/61119 credeconomiclosses.pdf, [Erișim 29 Ocak 2019].

Cook A.D.B., Shrestha M., Htet Z.B., (2018), An assessment of international emergency disaster response to the 2015 Nepal earthquakes, International Journal of Disaster Risk Reduction 31, 535-547.

Ekşi A., (2015), Kitlesel Olaylarda Hastane Öncesi Acil Să̆llk Hizmetleri, Kitapana Yayınları, İzmir, 312ss.

FEMA, (2004), Urban search and rescue technology needs: identification of needs, https://www.ncjrs.gov/pdffiles1/nij/grants/ 207771.pdf, [Erişim 11 Ocak 2019].

FEMA, (2006), National Urban Search \& Rescue (US\&R) Response System, Rescue Field Operations Guide, https://www.fema.gov/ pdf/emergency/usr/usr_23_20080205_rog.pdf, [Erişim 28 Kasım 2018].

FEMA, (2011), Emergency Planning, Independent Study 235.b, https://training.fema.gov/emiweb/is/is235b/is235b.pdf [Erișim 5 Haziran 2019].

Greatbatch I., Gosling R.J., Allen S., (2015), Quantifying search dog effectiveness in a terrestrial search and rescue environment, Wilderness \& Environmental Medicine, 26, 327-334.

INSARAG, (2015), INSARAG Guidelines, Volume I: Policy, https://www.insarag.org/images/stories/ INSARAG_Guidelines_V1_ Policy1.pdf, [Erişim 11 Aralık 2018].

Işık Ö., Aydınlığlu H.M., Koç S., Gündoğdu O., Korkmaz G., Ay A., (2012), Afet yönetimi ve afet odaklı sağlık hizmetleri, Okmeydanı Tip Dergisi 28(Ek say1 2), 82-123.

İlhan A.M, (2013), Afetler ve insani yardım operasyonlarında silahl kuvvetlerin rolü, Güvenlik Bilimleri Dergisi, 2(1), 107 - 129

İstanbul İtfaiyesi, (2014), Kentsel Arama-Kurtarma Eğitim Kitabı, İstanbul İtfaiyesi Eğitim Yayınları Serisi-9, 2. Baskı, 2014.

İSMEP, (2014), Acil Durum Hazırlık Kapasitesinin Artırlmasl, http://www.guvenliyasam.org/wp-content/uploads/2016/02/ KAPASITE.pdf, [Erişim 29 Ocak 2019].

Jinguo L., Yuechao W., Bin L., Shugen M., (2007), Current research, key performances and future development of search and rescue robots, Front. Mech. Eng. China, 2(4): 404-416.

Karaman Z.T., (2017), Afet Yönetimine Giriş ve Türkiye'de Örgütlenme, Bütünleşik Afet Yönetimi’nin İçinde (Karaman Z.T. ve Altay A. Ed.), Birleșik Matbaacılık Ltd. Ști., İzmir, ss.1-38.

Ko A., Lau H.YK., (2009), Robot assisted emergency search and rescue system with a wireless sensor network, International Journal of Advanced Science and Technology, 3, 69-78.

Murphy R.R., (2000), Marsupial and shape-shifting robots for urban search and rescue, IEEE Intelligent Systems and their Applications, 15(2), 14-19.

Murphy R.R., Tadokoro S., Nardi D., Jacoff A., Fiorini P., Choset H., Erkmen A.M., (2008), Search and Rescue Robotics, Springer Handbook of Robotics'ın içinde (Siciliano B. ve Khatib O., Ed.), Springer, Berlin, Heidelberg, ss.1151-1173. 
Narayanan R.G.L., Ibe O.C., (2012), A joint network for disaster recovery and search and rescue operations, Computer Networks, 56(14), 3347-337.

Noji E.K., Kelen G.D., Ermeni H., Oganessian A., Jones N.P., Sivertson K.T., (1990), The 1988 earthquake in Soviet Armenia: A case study, Annals of Emergency Medicine, 19(8), 891-897.

Ochoa S.F., Neyem A., Pino J.A., Borges M.R.S, (2007), Supporting group decision making and coordination in urban disasters relief, Journal of Decision Systems, 16(2), 143-172.

Ochoa S.F., Santo R., (2015), Human-centric wireless sensor networks to improve information availability during urban search and rescue activities, Information Fusion, 22, 71-84.

Osuka K., Kitajima H., (2003), Development of mobile inspection robot for rescue activities: MOIRA, Proceedings 2003 IEEE/RSJ International Conference on Intelligent Robots and Systems, Las Vegas, NV, ABD ss.27-31.

Peleg K., Reuveni H., Stein M., (2002), Earthquake disasters-lessons to be learned, Israel Medical Association Journal, 4(5), 361-365.

Peleg K., Kellermann A.L., (2012), Medical relief after earthquakes: 1 t's time for a new paradigm, Annals of Emergency Medicine 59(3), 188-190.

Peleg K., (2015), Notes from Nepal: Is there a better way to provide search and rescue?, Disaster Medicine and Public Health Preparedness, 9(6), 650-652.

Peleg K., Bodas M., Shenhar G., Adini B., (2018), Wisdom of (using) the crowds: Enhancing disasters preparedness through public training in light search and rescue, International Journal of Disaster Risk Reduction, 31, 750-757.

SARDA, (2019), Search \& Rescue Dog Association Scotland, http://www.sarda-scotland.org/, [Erişim 11 Ocak 2019].

TTK, (2019), Yer Altı Maden İşletmelerinde Arama Kurtarma ve TTK, Türkiye Taş Kömürü Kurumu (TTK), http://www.taskomuru.gov.tr/index.php?page=sayfagoster\&id=48, [Erişim 29 Ocak 2019].

Türker S., (2017), Arama Kurtarma Mevzuatı ve Ekipleri, Arama Kurtarma Bilgisi ve Etik Değerler'in İçinde (Pekkan E. Ed.), Anadolu Üniversitesi Yayınlar1, ss.26-48.

URL-1, (2019), The Five Phases of Emergency Management, https://www.bexar.org/694/Five-Phases, [Erişim 10 Haziran 2019].

URL-2, (1958), 7126 Sayll Sivil Savunma Kanunu, T.C. Resmi Gazete, Sayı: 9931, Tarih: 13/6/1958, http://www.mevzuat.gov.tr/ MevzuatMetin/1.3.7126.pdf, [Erişim 27 Ocak 2019].

URL-3, (2019), http://sakaryatarihi.blogcu.com/sakarya-tarihi/3493442, [Erişim 11 Ocak 2019].

URL-4, (2019), http://www.ktu.edu.tr/sivilsavunma-aramavekurtarmabilgileri, [Erişim 11 Ocak 2019].

URL-5, (1999), Sivil Müdafaa Kanunu Ile Belediye Kanununda Değişiklik Yapılmasına Dair Kanun Hükmünde Kararname, T. C. Resmi Gazete, Say1:23919, Tarih: 27.12.1999, https://www.resmigazete.gov.tr/arsiv/23919_1.pdf, [Erişim 27 Ocak 2019].

URL-6, (2009), Afet ve Acil Durum Yönetimi Başkanlığının Teşkilat ve Görevleri Hakkında Kañun, T.C. Resmi Gazete, Sayı: 27261, Tarih: 17.06.2009, https://www.resmigazete.gov.tr/eskiler/2009/06/20090617-1.htm, [Erişim 27 Ocak 2019].

URL-7, (2018), Güvenlik Kuvvetleri Komutanlı̆̆l, http://www.mucahit.net/Hakkinda/GenelBilgiler.aspx, [Erişim 11 Aralık 2018].

URL-8, (2019), http://www.akdf.org.tr/index.php/kurumsal/uye-derneklerimiz [Erişim 04 Ocak 2019].

URL-9, (2019), https://www.insarag.org/about/background, [Erişim 27 Ocak 2019].

URL-10, (2019), https://www.insarag.org/methodology/guidelines, [Erişim 27 Ocak 2019].

URL-11, (2018), https://www.insarag.org/, [Erişim 05 Kasım 2018].

URL-12, (2018), https://www.unocha.org/about-us/who-we-are, [Erişim 11 Kasım 2018].

URL-13, (2018), https://www.unocha.org/our-work/coordination/un-disaster-assessment-and-coordination-undac, [Erişim $11 \mathrm{Kas} ı \mathrm{~m}$ 2018].

URL-14, (2019), https://istanbul.afad.gov.tr/tr/17751/Arama-ve-Kurtarma-Birligimiz-Agir-Arama-Kurtarma-Ekibi-SiniflandirmasiYenilendi, [Erişim 11 Ocak 2019].

URL-15, (2019), https://www.afad.gov.tr/tr/17115/AFAD-Ankara-INSARAG-Agir-Arama-Kurtarma-Ekibi-Unvanini-Kazandi, [Erişim 11 Ocak 2019].

URL-16, (2019), http://www.diyarbakir.gov.tr/11012018-basin-duyurusu-afad, [Erişim 11 Ocak 2019].

URL-17, (2019), https://www.insarag.org/48-en/capacity-building/105-national-guidelines, [Erişim 11 Ocak 2019].

URL-18, (2019), https://www.afad.gov.tr/tr/22501/INSARAG-tan-Turkiye-ye-Ulusal-Akreditasyon-Sertifikasi, [Erişim 11 Ocak 2019].

URL-19, (2019), https://www.insarag.org/iec/news/550-ier-akut-team-turkey, [Erişim 11 Ocak 2019].

URL-20, (2019), https://www.afad.gov.tr/tr/4382/Hayat-Kurtaran-Kahramanlar-1, [Erişim 11 Ocak 2019].

URL-21, (2018), Life detectors/Search cameras, http://www.leadernorthamerica.com/products/search-rescue-equipment/life-detectors -search-cameras-624.html, [Erişim 15 Aralık 2018].

Usta G., Torpuş K., Küçük U., (2017), Afetlerde START triaj skalası, Doğal Afetler ve Çevre Dergisi, 3(2), 70-76.

Ye C., Ma S., Li B., (2006), Design and basic experiments of a shape-shifting mobile robot for urban search and rescue, International Conference on Intelligent Robots and Systems, Beijing, China, ss.3994-3999. 